\title{
Analysis of Causes of Delay in Middle and High Income Self-Build Housing Projects (SBHPs) in Wa, Ghana
}

\author{
Samuel Owusu Afram ${ }^{*}$, Anthony Bangdome-Dery ${ }^{2 *}$, Genevieve Ekua Eghan², \\ Titus Ebenezer Kwofie ${ }^{1}$ \\ ${ }^{1}$ Department of Architecture, College of Architecture and Planning, Kwame Nkrumah University of Science and \\ Technology (KNUST), Kumasi, Ghana \\ ${ }^{2}$ Building Technology \& Estate Management Department, Wa Polytechnic, Wa, Ghana \\ Email: "tonybangdome@gmail.com, ”aframso@yahoo.com
}

Received 21 October 2015; accepted 29 November 2015; published 2 December 2015

Copyright (C) 2015 by authors and Scientific Research Publishing Inc.

This work is licensed under the Creative Commons Attribution International License (CC BY).

http://creativecommons.org/licenses/by/4.0/

(c) () Open Access

\begin{abstract}
Self-build housing projects (SBHPs) among middle and high income developers are faced with many challenges that cause delay in the delivery time of the house(s). The focus of this paper is to analyse the factors that cause delay in SBHPs in order to identify the critical delay factors. Review of literature and expert input revealed 20 variables which were used in a structured questionnaire for data collection from owners, consultants and builders in Wa Municipality. Reliability test, t-test analysis and mean ranking were used in the data analysis. The results revealed that "Delay in obtaining permit from Local Authorities" was the first delay factor followed by "Poor site management and supervision". The delay factor ranked least was "Inadequate cost estimation and related details" from consultants. The paper recommends that Government agencies that regulate physical development should intensify public education, particularly on responsibilities and obligations, especially among self-builders. The paper recommends further study into labour-related issues as well as communication and information management among participants and its impact on self-build project success.
\end{abstract}

\section{Keywords}

Delays, Self-Build, Housing Projects, Ghana

\section{Introduction}

The housing sector in Ghana is supplied from mainly three sources that include profit house building mainly

*Corresponding authors.

How to cite this paper: Afram, S.O., Bangdome-Dery, A., Eghan, G.E. and Kwofie, T.E. (2015) Analysis of Causes of Delay in Middle and High Income Self-Build Housing Projects (SBHPs) in Wa, Ghana. Journal of Building Construction and Planning Research, 3, 171-179. http://dx.doi.org/10.4236/jbcpr.2015.34017 
controlled by real estate companies, rental house building operated by individuals and government organizations, and self-build housing mainly carried out by individuals or groups of individuals for habitation purposes [1]-[3]. However, Manu et al. (2009) alluded that the annual supply of housing units between 30,000 and 40,000 is woefully inadequate to meet the over one million housing deficit currently registered [4].

Unfortunately the many mass housing policies embarked on by various governments have largely failed. According to Arku (2009), the "Dispossessed Persons” Housing Scheme of the government of Gordon Guggisberg was halted in 1933 following its high cost [5]. Thus it served only one hundred and eighteen beneficiaries at the time. Recent housing schemes such as the State run Tema Development Cooperation and State Housing Cooperation, National Low Cost Housing, National Shelter Strategy, and Institutional Housing Scheme have failed to meet their intended targets at improving the housing stock of Ghana [1] [5]-[10].

Hence, over the years many individuals/families, especially the middle and high income earners, have embarked on self provision housing projects on their own in order to meet their housing needs mainly through the un-aided self help or self-build housing approach. It is important to note that middle and high income selfbuilders in Ghana, usually engage consultants to provide them with design and sometimes cost estimates and utilize labour-only contractors or builders to undertake the physical construction of the house in an incremental manner [11]. The self-build housing projects (SBHPs) delivery process in Ghana is however bedevilled with many challenges which result in delays in completing such individual residential housing projects. The challenges are as a result of factors emanating from various sources which include, owners (or self-builders), consultants, builders/subcontractors, regulatory bodies, building planning, land tenure, materials, labour, construction techniques, and suppliers among others [12]-[15]. The delays associated with the construction of SBHPs affect economic development of the nation, lead to increased housing deficit and affect the general well-being of the individual (owner), the family and the society at large [13] [16] [17].

SBHPs like other construction projects are exposed to delay factors as demonstrated by Aibinu and Jagboro (2002), Koushki et al. (2005), Assaf and Al-Hajji (2006), Fugar and Agyakwah-Baah (2010), Desai and Bhatt (2013), and Marzouk and El-Rasas (2014) in their various studies of construction delays [18]-[23]. These authors observed that construction delays can be grouped according to project participants and external factors. These include owner-related, consultant-related, builder-related, labour-related, government-related, land and tenure-related as well as external-related sources. Owner-related delays include difficulties in financing and paying for completed works, poor financial planning, non-consultation of right professionals for design documentation, changes to scope during construction among others. Consultant-related delays include unclear and inadequate details in drawings affecting cost, underestimation of cost of projects, poor communication, and insufficient availability of information before design, and inadequate cost information and related details.

Poor site management and supervision, ineffective planning and scheduling of project, delays in sub-contractor works, and rework due to errors during construction were also established as delays emanating from builder-related sources [23]. Labour-related delays according to Osei-Tutu and Adjei-Kumi (2009) [24] and Durdyev et al. (2012) [25] include lack of a credible artisanal recruitment system, unqualified workforce, inadequate labour management skills by owner, lack of on-site supervision of labour, cost and time of reworks, while government-related delays include delays in obtaining permit from Local Authorities, and lack of transparency with permit acquisition cost. The land and tenure-related delays include lengthy disputes/litigation on lands, and cumbersome and lengthy land acquisition procedures [26] [27]. Another delay factor beyond the control of project participants as observed by Koushki et al. (2005) [19] and Desai and Bhatt (2013) [22] is fluctuations in cost/currency.

While these delays seem to be very common in the developing world, in Ghana direct studies of construction delays have been limited to conventional building projects conducted by Fugar and Agyakwah-Baah (2010) [21]. Frimpong et al. (2003) conducted a study on delays in groundwater projects in Ghana [28]. The underlying causes of delays, particularly in SBHPs embarked on by middle and high income developers, have not been given adequate attention by researchers. The research is hinged on the assumption that owners, consultants and builders contribute significantly to delays experienced by self-build housing project among middle and high income self-builders. The aim of this paper therefore, is to investigate the causes of delay in self-build housing projects (SBHPs) in order to identify the underlying delay factors so as to improve the delivery time and enhance its contribution to the housing stock of Ghana. The objectives to guide this research include the following;

1) To identify from literature delay factors affecting residential building construction,

2) To conduct data collection and analysis of the delay factors affecting SBHPs in Ghana, 
3) To make recommendations on ways to reduce the impact of delays on SBHPs in Ghana.

It is envisaged that the study would expand the debate on housing in Ghana, create awareness among selfbuilders and other participants, and contribute to the general discourse on delays in building construction.

\section{Research Methodology}

Existing literature on delays in the construction industry in the developing world afforded the development of a theoretical framework of delays which was subjected to expert review leading to the establishment of a suitable framework of delays. A total of 20 delay factors were used to draw up a structured questionnaire divided into two sections. The first section requested general information in order to identify the profile of the respondents. The second section contained a list of delay factors on a Likert scale of 1 - 5 for ranking by respondents. Drawing on Blaikie (2000) [29] and Ahadzie (2007) [30] the numerical values were defined as follows; Strongly Disagree-1, Disagree-2, Average-3, Agree-4, and Strongly Agree-5. This facilitated the analysis of responses. Stratified random sampling technique was used to select three groups of respondents which include owners, consultants, and builders. Purposive sampling was however used in selecting 5 members from each group for piloting the questionnaire. The pilot survey enabled an enhancement of the questionnaire through the correction of minor grammatical errors.

\section{Results and Discussions}

Data from the field survey were analyzed on the SPSS (16) platform and presented in tables covering reliability test of variables, mean scores and one sample t-test results. Respondents profile has been discussed in the sub-section titled respondents profile and response rate below.

\subsection{Respondents Profile and Response Rate}

A total of 177 respondents were selected with a breakdown of 81 owners, 38 consultants, and 58 builders and given questionnaires. The field survey recorded in total a high response rate of $97.18 \%$ (Table 1). About $53.20 \%$ of owners indicated that they were fairly experienced with building construction, 51.43\% of consultants (architects, quantity surveyors, structural engineers, and clerks of work) have 11 - 15 years of experience in Self Build Housing projects. About $74.29 \%$ of consultants have handled between 11 and above 15 self-build houses in their practice. The builders recorded $48.28 \%$ with qualifications including HND, CTC $1 \& 2$ as main builders while $51.72 \%$ represented builders who work as foremen, site supervisors and sub-contractors with similar qualifications. 53.40\% of builders have executed over 15 houses constructed through the self-build approach.

\subsection{Reliability Test}

Cronbach (1951) [31], Nunnally (1978) [32] and Field (2005) [33] recommended that where the data was collected through the Likert scale questionnaire, Cronbach's Alpha coefficient should be used to test the reliability of the data. The Cronbach's Alpha coefficient of 0.842 was yielded after the computation in SPSS demonstrating good internal consistency. Table 2 presents the reliability statistics.

Table 1. Response rate (s) of the field survey.

\begin{tabular}{ccccc}
\hline ID & Group & Sample Size & No. Retrieved & Response Rate (\%) \\
\hline 1 & Owners & 81 & 79 & $97.53 \%$ \\
2 & Consultants & 38 & 35 & $92.11 \%$ \\
3 & Builders & 58 & 58 & $100.00 \%$ \\
& Total & 177 & 172 & $97.18 \%$ \\
\hline
\end{tabular}

Source: Author’s Field Survey, 2014.

Table 2. Reliability statistics.

\begin{tabular}{ccc} 
Cronbach's Alpha & N of Items & N \\
\hline 0.842 & 20 & 172 \\
\hline
\end{tabular}




\subsection{One Sample T-Test Results}

The t-test was conducted at a confidence interval of $95 \%$ and a high test value of 4.0 representing the minimum importance level below which the factor is considered not important. The mean scores resulting from the t-test enabled the ranking of the variables from the highest mean to the least mean score in a descending order. Table 3 and Table 4 tabulate the t-test results and the sample statistics respectively.

The mean ranking of underlying variables in Table 3 revealed that Delays in obtaining permit from Local Authorities (4.4535) is the highest ranked critical delay factor. The delays in obtaining relevant development permits for physical development has been blamed on inadequate human resource and logistical constraints among agencies and various divisions of the local authorities as observed by Mahama and Antwi (2006) [34] and Afrane and Asamoah (2011) [26]. However the results also indicate that the lowest ranked underlying delay criterion is Inadequate cost estimation and related details (4.0000). The general outlook of the results reflects that beyond the owner, consultants, builders and regulatory bodies significantly affect SBHP delivery.

Respondents also placed high premium on Poor site management and supervision as the second most important cause of delay in the criteria regarding self-build housing projects. Poor site organization and the very erratic nature of onsite construction works coupled with the poorly trained artisans account for the poor site management and supervision. Lengthy disputes/litigation on lands was ranked $3^{\text {rd }}$ while Cumbersome and lengthy

Table 3. Summary of t-test with mean rankings based on the test value of 4.0.

\begin{tabular}{|c|c|c|c|c|c|}
\hline \multicolumn{6}{|c|}{ One-Sample Statistics } \\
\hline & $\mathbf{N}$ & Mean & Std. Devn & $\begin{array}{l}\text { Std. Error } \\
\text { Mean }\end{array}$ & $\begin{array}{c}\text { Ranking } \\
\text { within Var. Grp }\end{array}$ \\
\hline Delays in obtaining permit from local authorities & 172 & 4.4535 & 0.83990 & 0.06404 & 1 \\
\hline Poor site management and supervision & 172 & 4.2733 & 0.99165 & 0.07561 & 2 \\
\hline Lengthy disputes/litigation on lands & 172 & 4.2500 & 0.87275 & 0.06655 & 3 \\
\hline Ineffective planning and scheduling of project & 172 & 4.2326 & 0.96941 & 0.07392 & 4 \\
\hline Lack of a credible artisanal recruitment system & 172 & 4.2267 & 0.94948 & 0.07240 & 5 \\
\hline Unqualified workforce & 172 & 4.1744 & 0.89432 & 0.06819 & 6 \\
\hline Lack of transparency with permit acquisition cost & 172 & 4.1512 & 1.01472 & 0.07737 & 7 \\
\hline Fluctuations in cost/currency & 172 & 4.1105 & 0.75278 & 0.05740 & 8 \\
\hline Delays in sub-contractors work & 172 & 4.1047 & 0.82404 & 0.06283 & 9 \\
\hline Unclear and inadequate details in drawings affecting cost & 172 & 4.0988 & 0.75440 & 0.05752 & 10 \\
\hline Cumbersome and lengthy land acquisition procedures & 172 & 4.0988 & 0.90263 & 0.06882 & 11 \\
\hline Inadequate labour management skills by owner & 172 & 4.0872 & 0.74021 & 0.05644 & 12 \\
\hline Underestimation of costs of projects & 172 & 4.0872 & 0.96637 & 0.07369 & 13 \\
\hline Lack of on-site supervision of labour & 172 & 4.0640 & 0.68525 & 0.05225 & 14 \\
\hline Cost and time of reworks & 172 & 4.0465 & 0.90362 & 0.06890 & 15 \\
\hline Poor communication between consultant and other parties & 172 & 4.0465 & 1.04189 & 0.07944 & 16 \\
\hline Delay in finance and payments for completed work by owner & 172 & 4.0407 & 0.99330 & 0.07574 & 17 \\
\hline Rework due to errors during construction & 172 & 4.0349 & 0.80855 & 0.06165 & 18 \\
\hline Insufficient availability of information before design & 172 & 4.0058 & 0.92083 & 0.07021 & 19 \\
\hline Inadequate cost estimation and related details & 172 & 4.0000 & 0.94281 & 0.07189 & 20 \\
\hline \multicolumn{6}{|c|}{$\begin{array}{c}\text { Test Value }=4.0 \\
\text { Confidence Interval }=\mathbf{9 5 \%}, \text { Number of } \text { Items }=20\end{array}$} \\
\hline
\end{tabular}


Table 4. Results of one sample test.

\begin{tabular}{|c|c|c|c|c|c|c|}
\hline \multicolumn{7}{|c|}{ One-Sample Test } \\
\hline & \multicolumn{6}{|c|}{ Test Value $=4.0$} \\
\hline & \multirow{2}{*}{$\mathbf{t}$} & \multirow{2}{*}{ df } & \multirow{2}{*}{$\begin{array}{c}\text { Sig. } \\
\text { (2-tailed) }\end{array}$} & \multirow{2}{*}{$\begin{array}{c}\text { Mean } \\
\text { Difference }\end{array}$} & \multicolumn{2}{|c|}{$\begin{array}{l}\text { 95\% Confidence } \\
\text { Interval of the Difference }\end{array}$} \\
\hline & & & & & Lower & Upper \\
\hline Delays in obtaining permit from local authorities & 7.081 & 171 & 0.000 & 0.45349 & 0.3271 & 0.5799 \\
\hline Poor site management and supervision & 3.614 & 171 & 0.000 & 0.27326 & 0.1240 & 0.4225 \\
\hline Lengthy disputes/litigation on lands & 3.757 & 171 & 0.000 & 0.25000 & 0.1186 & 0.3814 \\
\hline Ineffective planning and scheduling of project & 3.146 & 171 & 0.002 & 0.23256 & 0.0867 & 0.3785 \\
\hline Lack of a credible artisanal recruitment system & 3.132 & 171 & 0.002 & 0.22674 & 0.0838 & 0.3697 \\
\hline Unqualified workforce & 2.558 & 171 & 0.011 & 0.17442 & 0.0398 & 0.3090 \\
\hline Lack of transparency with Permit acquisition cost & 1.954 & 171 & 0.052 & 0.15116 & -0.0016 & 0.3039 \\
\hline Fluctuations in cost/currency & 1.925 & 171 & 0.056 & 0.11047 & -0.0028 & 0.2238 \\
\hline Delays in sub-contractors work & 1.666 & 171 & 0.098 & 0.10465 & -0.0194 & 0.2287 \\
\hline Unclear and inadequate details in drawings affecting cost & 1.718 & 171 & 0.088 & 0.09884 & -0.0147 & 0.2124 \\
\hline Cumbersome and lengthy land acquisition procedures & 1.436 & 171 & 0.153 & 0.09884 & -0.0370 & 0.2347 \\
\hline Inadequate labour management skills by owner & 1.545 & 171 & 0.124 & 0.08721 & -0.0242 & 0.1986 \\
\hline Underestimation of costs of projects & 1.184 & 171 & 0.238 & 0.08721 & -0.0582 & 0.2327 \\
\hline Lack of on-site supervision of labour & 1.224 & 171 & 0.223 & 0.06395 & -0.0392 & 0.1671 \\
\hline Cost and time of reworks & 0.675 & 171 & 0.501 & 0.04651 & -0.0895 & 0.1825 \\
\hline Poor communication between consultant and other parties & 0.585 & 171 & 0.559 & 0.04651 & -0.1103 & 0.2033 \\
\hline Delay in finance and payments for completed work by owner & 0.537 & 171 & 0.592 & 0.04070 & -0.1088 & 0.1902 \\
\hline Rework due to errors during construction & 0.566 & 171 & 0.572 & 0.03488 & -0.0868 & 0.1566 \\
\hline Insufficient availability of information before design & 0.083 & 171 & 0.934 & 0.00581 & -0.1328 & 0.1444 \\
\hline Inadequate cost estimation and related details & 0.000 & 171 & 1.000 & 0.00000 & -0.1419 & 0.1419 \\
\hline
\end{tabular}

land acquisition procedures ranked $11^{\text {th }}$ delay factor perhaps due to the back and forth process of dealing with landlords (whether allodial or family) and the difficult situation of "double sale" of the land to a third party. Respondents agreed that lengthy disputes and litigation directly affect progress of SBHPs since construction works are stalled sometimes until a resolution is arrived at by disputing parties.

It is worth noting that the $4^{\text {th }}$ ranked delay factor is Ineffective planning and scheduling of project. Fugar and Agyakwah-Baah (2010) corroborated the importance of this factor with the explanation that builders in developing countries prefer to make profit rather than pay highly skilled staff to manage and supervise their projects [21]. Durdyev et al. (2012) suggested that quality onsite management systems are required to overcome poor site management and supervision [25]. Koushki et al. (2005) however reported that in Kuwait, owners hired supervising engineers to independently supervise the progress of works and found that there was marked reduction in time-delay [19]. Owners of self-build projects should consider engaging qualified supervising engineers on their project sites.

Respondents ranked Lack of a credible artisanal recruitment system as the $5^{\text {th }}$ most important delay criterion. Most of the builders in the study area do not have permanent workforce in their firms and thus recruit both skilled and unskilled labour when commencing a project. This is because there is no credible labour recruitment system available to supply labour force for construction activities. It was observed that builders seldom use ad- 
vertisement to reach labour force for recruitment but through word of mouth. The process of recruiting the required skilled and unskilled labour therefore takes considerable time which eventually affects the project performance. Following closely in $6^{\text {th }}$ position is the criterion Unqualified workforce. This is in agreement with results of similar studies [25] [35] that revealed lack of skilled workforce and labour performance as significant delay factors in projects. As asserted earlier by Fugar and Agyakwah-Baah (2010), there is available qualified workforce but the attraction for profit by builders is the bane for this problem [21]. Certainly, unqualified workforce literally results in poor quality and reworks which significantly contribute to time-delay in projects. The use of unqualified workforce onsite therefore affects the performance of workers in meeting quality standards.

Even though Cost and Time of Reworks is recognized as a significant contributor to construction delays, respondents ranked this criterion as the $15^{\text {th }}$ most important delay criterion. The lengthy time gaps between onsite activities affect the integrity of work done coupled with inadequate design details to support builders' activities during construction. It is therefore not surprising that respondents ranked the criterion Unclear and inadequate details in drawings affecting cost as the $10^{\text {th }}$ most important delay criterion. Consultants have the responsibility of providing detailed design documentation from which cost estimates are extracted. Unfortunately, this is not the case for SBHPs. For instance, $46.30 \%$ of owners interviewed indicated that they have no experience at all regarding construction and construction related documentations. Hence, the adequacy of construction documentation cannot be verified by many owners. According to Durdyev et al. (2012) inadequate design details results in inaccurate project cost estimation with significant contribution to project delay in Turkey [25]. Long et al. (2004) [36] and Le-Hoai et al. (2008) [37] in separate studies have earlier suggested that project cost estimation forms a very critical part of project success and should be properly and diligently carried out at the pre-construction phase. In the same light, consultants should give priority to detailing drawings adequately and producing associated cost estimates to guide owners during construction.

Field (2005) recommended that when variables record standard deviations less than 1.0, it brings to bare the consistency in agreement among respondents [33]. It is important to note that two variables registered standard deviations slightly greater than 1.0. That is, Lack of transparency with Permit acquisition cost (1.01472; ranked $\left.7^{\text {th }}\right)$ and Poor communication between consultant and other parties (1.04189; ranked $16^{\text {th }}$ ). This is an indication that respondents had various interpretations on these two variables. Poor communication between consultant and other parties as a delay criterion affects progress, especially at the inception and implementation phases of any project. Unfortunately communication among parties remains a challenge especially in SBHPs where mostly informal methods are used by parties. Communication should therefore be the bridge that allows coordination of activities among parties. Azhar et al. (2008) [35] and Durdyev et al. (2012) [25] support this from their study of delays and cost overruns in building projects. The results showed that, lack of communication between parties, results in delay and cost overruns of projects. In fact, Durdyev et al. (2012) alluded that poor communication between project teams and parties is not a good practice and should be recognised as such [25].

Delay in finance and payments for completed work by owner, Rework due to errors during construction, and Insufficient availability of information before design were ranked $17^{\text {th }}, 18^{\text {th }}$, and $19^{\text {th }}$ respectively. Adequate financial capacity among owners (self-builders) in Ghana is a challenge. Unfortunately, this is compounded by poor financial planning on the part of owners which underscores the importance of consulting the right professionals to provide adequate design and cost information [23] [38] [39]. In fact, the provision of sufficient design information eliminates the need for reworks due to errors during construction, since every aspect of the project would be considered and presented in the design works.

\section{Conclusions and Recommendations}

This paper set out to investigate causes of delay in self-build housing projects in Ghana. Responses were obtained from project participants through questionnaire surveys. One sample t-test was computed on the data collected and mean statistics were used to rank the factors in order of importance with regards to the factor's contribution to delay in SBHPs. The research can conclude that the most important delay factor from the empirical analysis is Delays in obtaining permit from Local Authority followed by Poor site management and supervision, while Inadequate cost estimation and related details emerged the least ranked factor causing delay in SBHPs.

In order to overcome these underlying causes of delay in SBHPs, the following recommendations have been outlined. They include that;

- Government agencies mandated to issue planning and development permits need to vigorously engage the 
general public, especially self-builders, so as to educate them on their responsibilities and obligations. The agencies need to identify innovative ways of engaging the public and enhancing their resource base to meet the demands of developers.

- Owners from the onset should engage consultants with the requisite experience to provide affordable consultancy services to cover design and construction activities on the residential building project.

- Owners need to perform due diligence to ascertain the ownership status of lands at the Lands Commission before purchasing so as to avoid disputes and litigations. Owners engaging consultants from the onset can be supported in the verification land ownership.

- Owners should ensure timely approval and payments to builders for work completed through a payment schedule agreed on and as recommended by the consultant.

- Consultants in collaboration with the builder should break down the construction stage into phases, taking into consideration the cash flow status of both the owner and builder.

- Consultants should establish control systems to manage disputes and enhance communication between parties so as to reduce variations and related costs.

- Fees and charges could be on time basis so as to meet the service charges by consultants. Percentage and lump sum charges have generally been considered expensive and artificial and thus, time charges tied with activities are explicable for most clients especially self-builders.

- Builders should develop and employ a comprehensive work plan in executing the house project.

- Builders should develop and employ comprehensive financial and cash flow plans with respect to the suggested phases of construction.

- For building works that require expertise, builders should allow the experts with the required expertise and reputation, approved by the consultants and owners to execute that aspect of the works.

There is the need for assessment of the potential(s) of an artisanal recruitment system in order to provide a platform for self-builders to directly engage artisans on their construction sites. There is therefore the need for further research into the labour-related issues as well an in-depth understanding of communication and information among project participants in the self-build housing process.

\section{References}

[1] Tipple, G. and Korboe, D. (1998) Housing Policy in Ghana: Towards a Supply-Oriented Future. Habitat International, 22, 245-257. http://dx.doi.org/10.1016/S0197-3975(98)00009-5

[2] Gough, K.V. and Yankson, P. (2010) A Neglected Aspect of the Housing Market: The Caretakers of Peri-Urban Accra, Ghana. Urban Studies, 48, 793-810. http://dx.doi.org/10.1177/0042098010367861

[3] UN-Habitat (2011) Ghana Housing Profile. United Nations Human Settlement Programme, Nairobi.

[4] Manu, F.W., Baiden-Amissah, P.D., Adobor, D.C.I. and Danquah, J.A. (2009) Mitigating Global Climatic Change through the Use of Green Building Materials. National Housing Conference Proceedings at STEPRI. C.S.I.R., 208-217.

[5] Arku, G. (2009) The Economics of Housing Programmes in Ghana, 1929-66. Planning Perspectives, 24, $281-300$. http://dx.doi.org/10.1080/02665430902933952

[6] Konadu-Agyemang, K. (2001) The Political Economy of Housing and Urban Development in Africa: Ghana’s Experience from Colonial Times to 1998. Praeger, Westport, CT/London, 137-138.

[7] Bank of Ghana (2007) The Housing Market in Ghana. Research Department of Bank of Ghana, Ghana.

[8] Obeng-Odoom, F. (2009) Has the Habitat for Humanity Housing Scheme Achieved Its Goal? A Ghanaian Case Study. Journal of Housing and the Built Environment, 24, 67-84. http://dx.doi.org/10.1007/s10901-008-9128-7

[9] Kwofie, T.E., Adinyira, E. and Botchway, E. (2011) Historical Overview of Housing Provision in Pre- and Post-Independent(ce) Ghana. Laryea, S., Leringer, R. and Hughes, W., Eds., West Africa Built Environment Research (WABER) Conference, Accra, 19-21 July 2011, 541-557.

[10] Bangdome-Dery, A., Eghan, G.E. and Afram, S.O. (2014) Overview of Self-Help (Self-Build) Housing Provision in Ghana: Policies and Challenges. Developing Country Studies, 4, 77-89.

[11] Ahadzie, D.K. and Badu, E. (2011) Success Indicators for Self-Build Houses in Two Ghanaian Cities. Journal of Science and Technology, 31, 86-96.

[12] Biitir, S.B. (2009) Provision of Affordable Housing for Low Income Groups in Tamale Metropolitan Area through Self-Help Housing Approach. Un-Published Master of Philosophy Thesis, Department of Land Economy, Kwame Nkrumah University of Science \& Technology, Kumasi. 
[13] Afrane, S. and Amoako, C. (2011) Peri-Urban Development in Kumasi. In: Adarkwa, K.K., Ed., Future of the Tree: Towards Growth and Development of Kumasi, University Printing Press, Kwame Nkrumah University of Science and Technology, Kumasi, 92-110.

[14] Soliman, A.M. (2012) The Egyptian Episode of Self-Build Housing. Habitat International, 36, 226-236. http://dx.doi.org/10.1016/j.habitatint.2011.08.004

[15] Oyedokun, T.B., Adewusi, A.O., Ojo, B., Onakoya, B.O. and Akinbogun, S.P. (2012) Constraints to Land Accessibility by Urban Residents in Akure, Nigeria. Proceedings of the 4th West Africa Built Environment Research (WABER) Conference, Abuja, 24-26 July 2012, 1249-1260.

[16] Kamau, P.K. (2002) Enhancing Housing Development and Ownership, Prospects for Individual Housing Development in Nairobi, Kenya. Unpublished PhD Thesis, University of Tsukuba, Tsukuba.

[17] Badu, E., Owusu-Manu, D., Edwards, D.J. and Holt, G.D. (2011) Innovative Financing (IF) of Infrastructure Projects in Ghana: Conceptual and Empirical Observations. Engineering Project Organization Journal, 1, 255-268. http://dx.doi.org/10.1080/21573727.2011.597744

[18] Aibinu, A. and Jagboro, G. (2002) The Effects of Construction Delays on Project Delivery in Nigerian Construction Industry. International Journal of Project Management, 20, 593-599. http://dx.doi.org/10.1016/S0263-7863(02)00028-5

[19] Koushki, P.A., Al-Rashid, K. and Kartam, N. (2005) Delays and Cost Increase in the Construction of Private Residential Projects in Kuwait. Construction Management and Economics, 23, 285-294. http://dx.doi.org/10.1080/0144619042000326710

[20] Assaf, S.A. and Al-Hajji, S. (2006) Causes of Delay in Large Construction Projects. International Project Management, 24, 349-357. http://dx.doi.org/10.1016/j.ijproman.2005.11.010

[21] Fugar, F.D.K. and Agyakwah-Baah, A.B. (2010) Delays in Building Construction Projects in Ghana. Australasian Journal of Construction Economics and Building, 10, 103-116. http://dx.doi.org/10.1016/j.ijproman.2005.11.010

[22] Desai, M. and Bhatt, R. (2013) Critical Causes of Delay in Residential Construction Projects: Case Study of Central Gujarat Region of India. International Journal of Engineering Trends and Technology (IJETT), 4, 762-768.

[23] Marzouk, M.M. and El-Rasas, T.I. (2014) Analyzing Delay Causes in Egyptian Construction Projects. Journal of Advanced Research, 5, 49-55. http://dx.doi.org/10.1016/j.jare.2012.11.005

[24] Osei-Tutu, E. and Adjei-Kumi, T. (2009) An Evaluation of Housing Cost Trends in Ghana for the Period 1991-2008. Proceedings of National Housing Conference, Accra, 7-8 October 2009, 166-182.

[25] Durdyev, S., Ismail, S. and Abu Bakar, N. (2012) Factors Causing Cost Overruns in Construction of Residential Projects; Case Study of Turkey. International Journal of Science and Management, 1, 3-12.

[26] Afrane, S. and Asamoah, P.K.B. (2011) Housing Situation in Kumasi. In: Adarkwa, K.K., Ed., Future of the Tree: Towards Growth and Development of Kumasi, University Printing Press, Kwame Nkrumah University of Science and Technology, 69-91.

[27] Hammond, D.N.A. (2011) Harmonizing Land Policy and the Law for Development in Kumasi. In: Adarkwa, K.K., Ed., Future of the Tree: Towards Growth and Development of Kumasi, University Printing Press, Kwame Nkrumah University of Science and Technology, 55-68.

[28] Frimpong, Y., Oluwoye, J. and Crawford, L. (2003) Causes of Delay and Cost Overruns in Construction of Groundwater Projects in a Developing Country: Ghana as a Case Study. International Journal of Project Management, 21, 321-326. http://dx.doi.org/10.1016/S0263-7863(02)00055-8

[29] Blaikie, N. (2000) Designing Social Research. Polity Press, Cambridge.

[30] Ahadzie, D.K. (2007) A Model for Predicting the Performance of Project Managers in Mass House Building Projects. PhD Thesis, University of Wolverhampton, Wolverhampton.

[31] Cronbach, L.J. (1951) Coefficient Alpha and the Internal Structure of Tests. Psychometrika, 16, 297-333. http://dx.doi.org/10.1007/BF02310555

[32] Nunnally, J.C. (1978) Psychometric Theory. 2nd Edition, McGraw-Hill, New York.

[33] Field, A. (2005) Discovering Statistics, Using SPSS for Windows. Sage Publications, London.

[34] Mahama, C. and Antwi, A. (2006) Land and Property Markets in Ghana, Discussion Paper, Prepared by Royal Institution of Chattered Surveyors. World Urban Forum III, Vancouver, 19-23 June 2006. http://www.urbanlandmark.org.za/downloads/Land property market-ghana.pdf

[35] Azhar, N., Farooqui, R.U. and Ahmed, S.M. (2008) Cost Overrun Factors in Construction Industry of Pakistan. Proceedings of the 1st ICCIDC-I Conference, Karachi, 4-5 August 2008, 499-508.

[36] Long, N.D., Ogunlana, S., Quang, T. and Lam, K.C. (2004) Large Construction Projects in Developing Countries: A 
Case Study from Vietnam. International Journal of Project Management, 22, 553-561. http://dx.doi.org/10.1016/j.ijproman.2004.03.004

[37] Le-Hoai, L., Lee, Y.D. and Lee, J.Y. (2008) Delay and Cost Overruns in Vietnam Large Construction Projects: A Comparison with Other Selected Countries. KSCE Journal of Civil Engineering, 12, 367-377. http://dx.doi.org/10.1007/s12205-008-0367-7

[38] Abd El-Razek, M.E., Bassioni, H.A. and Mobarak, A.M. (2008) Causes of Delay in Building Construction Projects in Egypt. Journal of Construction Engineering and Management, 134, 831-841. www.ascelibrary.org/toc/jcemd4/134/11

[39] Sweis, G., Sweis, R., Abu Hammad, A. and Shboul, A. (2008) Delays in Construction Projects: The Case of Jordan. International Journal of Project Management, 26, 665-674. http://dx.doi.org/10.1016/j.ijproman.2007.09.009 